\title{
Genetic susceptibility to HPV infection and cervical cancer
}

P.C. Maciag and L.L. Villa
Instituto Ludwig de Pesquisa sobre o Câncer, São Paulo, SP, Brasil

\author{
Correspondence \\ L.L. Villa \\ Instituto Ludwig de Pesquisa \\ sobre o Câncer \\ Rua Prof. Antônio Prudente, 109 \\ 40 andar \\ 01509-010 São Paulo, SP \\ Brasil \\ Fax: + 55-11-270-7001 \\ E-mail: ludwig2@ node1.com.br \\ Presented at the I International \\ Symposium on "Signal Transduction \\ and Gene Expression in Cell \\ Proliferation and Differentiation", \\ São Paulo, SP, Brasil, \\ August 31-September 2, 1998. \\ Research supported by FAPESP
}

Received December 21, 1998 Accepted March 2, 1999

\section{Abstract}

Squamous cell carcinoma of the cervix (SCCC) is one of the leading causes of death in developing countries. Infection with high-risk human papillomavirus (HPV) is the major risk factor to develop malignant lesions in the cervix. Polymorphisms of the MHC and p53 genes seem to influence the outcome of HPV infection and progression to SCCC, although controversial data have been reported. MHC are highly polymorphic genes that encode molecules involved in antigen presentation, playing a key role in immune regulation, while p53 is a tumor suppressor gene that regulates cell proliferation. The HPV E6 protein from high-risk types binds $\mathrm{p} 53$ and mediates its degradation by the ubiquitin pathway. The role of these polymorphisms in genetic susceptibility to HPV infection and to SCCC remains under investigation.

\section{Carcinoma of the uterine cervix and human papillomavirus}

Squamous cell carcinoma of the cervix (SCCC) is one of the most frequent carcinomas affecting women, predominantly in developing countries (1). SCCC and its precursor lesions (cervical intraepithelial neoplasias or CINs) behave as sexually transmitted diseases. Epidemiological and molecular studies have implicated human papillomavirus (HPV) as the major risk factor to develop malignant lesions in the uterine cervix (2). HPV DNA is found in more than $90 \%$ of the samples from patients with SCCC, with HPV 16 being the type most frequently found (3). SCCC and HPV infections share several risk factors related to sexual behavior, including age at first intercourse and increas-

\section{Key words}

- Human papillomavirus

- Cervical cancer

- HLA

- p53

- Polymorphism ing number of sexual partners in a lifetime (4).

Papillomaviruses are epitheliotropic viruses present in the skin and mucosa of several animals. In humans, more than 70 types have been described (5). Mucosal and genital HPVs, consisting of about 30 types, are divided into low-risk (HPVs 6, 11, 42, 43, and 44) and high-risk (HPVs 16, 18, 31, 33, $35,45,51,52$ and 56), according to their presence in malignant lesions of the cervix (6).

The genome of these viruses is a doublestranded DNA molecule of about $8000 \mathrm{bp}$. Three genomic regions have been identified: a late region (L), an early region (E), and a long control region (LCR). The early genes E1 and E2 encode proteins involved in viral DNA replication and control of viral tran- 
scription (5). The products of genes E6 and E7 are essential in the process of HPVinduced cellular immortalization and transformation $(7,8)$. The late genes L1 and L2 encode the viral capsid proteins (5).

HPV genomes are found as episomes in the nucleus of infected cells of the normal cervix, where infective viral particles can be isolated. However, in some low-grade and in most of the high-grade lesions of the uterine cervix, including cancer, HPV genomes are found integrated into the host genome (9). A disruption of the E1-E2 region is required for HPV genome integration. This event results in an increased expression and stabilization of the E6 and E7 transcripts (10).

The E6 protein from high-risk HPVs binds cellular p53 (11), promoting the degradation of $\mathrm{p} 53$ by the cellular ubiquitin proteolysis system (12). The E7 protein interacts with pRB and inactivates this cellular protein (13). As a consequence, E2F transcription factor is released from pRB-E2F complex, leading to transcriptional activation of several genes involved in cell proliferation (14). Such interactions of HPV E6 and E7 proteins interfere with two major pathways involved in the control of the cell cycle.

\section{Persistence of HPV infections}

Infection with high-risk HPV types is frequent among sexually active women, with incidence ranging from 15 to $40 \%$ (2). When additional cervical specimens are taken from these women in follow-up surveys, the majority of the infections are found to be transient (15). However, a small proportion of infected women has persistent infection with high-risk HPV types. Previous reports have demonstrated that women persistently infected with oncogenic HPV types are more likely to develop malignant cervical lesions (16) and progressive dysplasia (17). Furthermore, persistent HPV infections associated with a high viral load are considered to be risk factors for persistent cervical lesions
$(18,19)$. This could be explained by intrinsic features of some HPV types, particularly those of the high-risk type, but very little is known in this respect.

It is also likely that the genetic background of the host influences the persistence of HPV infection. Among genetic factors that could participate in the susceptibility to SCCC and disease outcome, polymorphic genes of the major histocompatibility complex (MHC), as well as a particular polymorphism in the p53 gene have been intensely investigated.

\section{MHC genes and cervical cancer}

MHC genes are highly polymorphic genes that encode proteins implicated in antigen presentation to $\mathrm{T}$ cells. The MHC class I genes (HLA-A, HLA-B and HLA-C, in humans) are expressed in all nucleated cells and their products present antigenic peptides to $\mathrm{CD}^{+} \mathrm{T}$ cells (cytotoxic $\mathrm{T}$ cells). The expression of MHC class II genes is restricted to professional antigen-presenting cells (APCs) and activated lymphocytes. Class II molecules (HLA-DR, HLA-DQ and HLA-DP, in humans) present antigenic peptides to $\mathrm{CD}^{+} \mathrm{T}$ cells (helper $\mathrm{T}$ cells) (20). The MHC genes play a key role in the regulation of the immune response (21).

Some studies have indicated a role for MHC genes in immunological events related to papillomavirus infection, such as wart regression and response to HPV epitopes $(22,23)$. Furthermore, it has been reported that MHC class II genes are involved in genetic susceptibility to cervical cancer in humans. Positive and negative associations between HLA alleles and SCCC or HPV infection have been described. Table 1 lists the results obtained in several studies (see Refs. 24-42) carried out on different populations. These findings show that the associated MHC class II alleles may change according to the population analyzed. On the other hand, some associations are frequently 
Table 1 - HLA associations with HPV-associated cervical intraepithelial neoplasia (CIN) and squamous cell carcinoma of the cervix (SCCC).

apositive associations are indicated by OR values above 1 , and negative associations by values lower than 1 . \#Allele frequencies in the control group were obtained from International Histocompatibility Workshops. ${ }^{*}$ Control group is not from the same population. CIS - Carcinoma in situ; LSIL - low-grade squamous intraepithelial lesion; HSIL - high-grade squamous intraepithelial lesion.

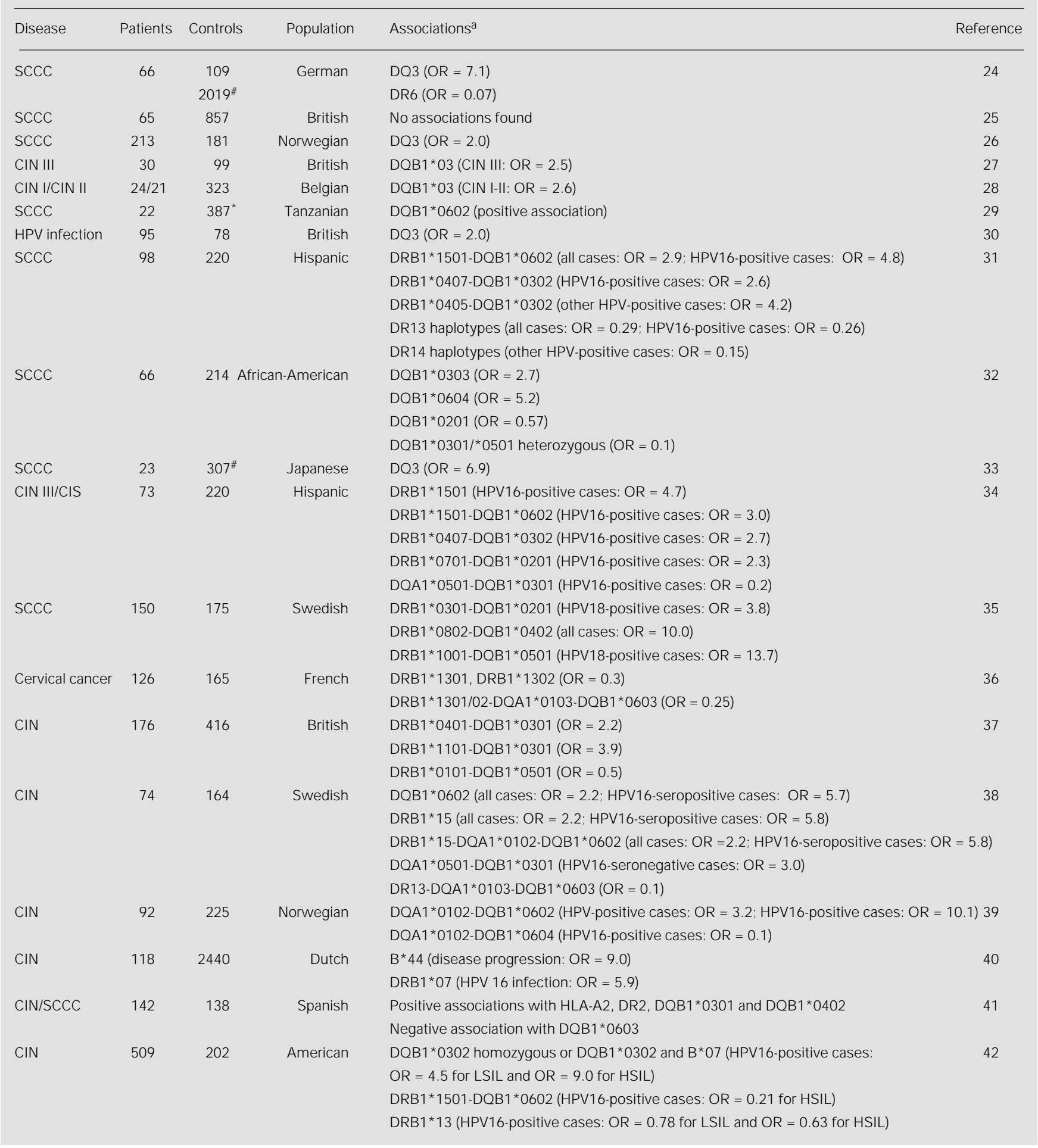


found, even for different ethnic groups. Positive associations between HLA-DQB $1 * 03$ and SCCC were described in Caucasian, Black and Oriental populations $(24,32,33)$. Haplotype DRB1*15-DQB1*0602, and its individual alleles were found to be positively associated with SCCC in several studies conducted on Caucasian, Hispanic and Black populations $(29,31,38)$, although negative association with this haplotype was also reported (42). Furthermore, negative associations frequently involved the DRB $1 * 13$ alleles $(31,36)$. Some alleles and haplotypes were found to be positively and negatively associated with SCCC depending on the population studied. Our group, in collaboration with Dr. Petzl-Erler, Federal University of Paraná, is investigating the HLA class II allele distribution in women with HPV infection and SCCC in Brazilian populations.

An interesting result reported by Ellis et al. (43) indicated a possible explanation for HLA associations with HPV infection and SCCC. The authors identified in a large proportion of HLA-B7 patients an HPV16 variant which has a point mutation in the E6 protein that alters an HLA-B7 binding epitope. This modification could affect the proper antigenic recognition by cytotoxic $\mathrm{T}$ lymphocytes (CTLs). The effect of these altered peptide ligands in impairing CTL function has been recently demonstrated (44).

An HPV 16 variant that presents a base change at nucleotide $350(\mathrm{~T} \rightarrow \mathrm{G}: \mathrm{Leu} \rightarrow \mathrm{Val})$, as compared to the prototype, was associated with persistent HPV infections (16). However, no correlations were observed between HLA class I and class II genes and HPV variants when the E6 and E7 sequences were analyzed (40). In another study, HPV 16 and HPV18 E2 variants that co-segregate with the variant at position 350 were detected more frequently in DRB $1 * 0401$ DQB $1 * 0301$ and DRB $1 * 1101-\mathrm{DQB} 1 * 0301$ carriers (45).

Several reasons may be responsible for the conflicting results about the association between MHC genes and HPV-associated cervical disease. Other genes, closely linked to HLA genes, may be involved in the genetic susceptibility to papillomavirus infection and SCCC development. Different linkage disequilibrium patterns among populations may be responsible in part for the conflicting associations reported. Several non-HLA genes located in the MHC region also participate in the immune response and are related to disease susceptibility. An increased risk for death or severe neurological disease due to cerebral malaria was associated with the TNF2 allele (46), a variant of the TNF- $\alpha$ gene promoter region, located in the MHC class III region. A susceptibility gene for alveolar lung tumors in the mouse was mapped to the $\mathrm{H}-2$ complex class III region (47).

Besides associations for SCCC and HPV infection, genetic susceptibility to two Epstein-Barr virus-associated tumors, namely nasopharyngeal carcinoma (48) and Hodgkin disease (49), was linked to the HLA class I and class II regions, respectively. Recently, an increased frequency of the DRB $1 * 1501$ and DQB $1 * 0602$ alleles was found in human T-cell lymphotropic virus type I (HTLV-I) carriers (50). These viruses are associated with adult T-cell leukemia and lymphoma. In cutaneous melanoma, an increased risk was reported for HLA-DQB $1 * 0301$ carriers (51). It is likely that HLA genes influence the development of virus-associated malignant diseases since these genes play a role in the regulation of the immune response against these viruses.

\section{Immunological response against HPV}

In spontaneously regressing plane warts, the cellular infiltrate is composed mainly of $\mathrm{T}$ cells and mononuclear phagocytes (52). Furthermore, E6- and E7-specific CTLs were detected in the peripheral blood of patients with high grade lesions (53) and infiltrating HPV-associated tumoral tissues (54). It was 
also demonstrated that the HPV E7 protein is a tumor-specific antigen important in animal models of tumor rejection (55). These results indicate that the cellular immune response is very important in the clearance of HPV infections. Furthermore, patients infected with human immunodeficiency virus (HIV) have a higher prevalence of HPV infection and malignant anogenital lesions. In HIV-1-positive women, Vernon et al. (56) showed that the more immunocompromised is the patient, the more likely she is to carry persistent HPV infections.

An evaluation of the immune response in the context of HPV infection and disease progression was performed by lymphoproliferative assays. De Gruijl et al. (57) found a stronger $\mathrm{T}$ helper cell proliferative response against HPV16 E7 peptides in patients with persistent HPV infection. On the other hand, Kadish et al. (58) observed that an efficient lymphoproliferative response specific for HPV16 E6 and E7 peptides was correlated with clearance of HPV infection and CIN regression. Other HPV proteins such as E1, E2 and L1 are also capable to elicit lymphocyte proliferation $(59,60)$. In animal models, a positive lymphoproliferative response to cottontail rabbit papillomavirus L1 and L2 protein was detected in animals with regressing papilloma (61).

The evaluation of cytokine patterns in HPV-associated diseases has revealed that alterations in the cytokine balance are related to disease outcome. Depending on the set of cytokines secreted, $T$ helper cells are divided into Th1 cells, which produce IL-2, IFN- $\gamma$ and TNF- $\beta$, and Th 2 cells, which produce IL-4, IL-5, IL-10 and IL-13 (62). While Th1 cytokines stimulate the cellular immune response, Th2 cytokines repress it. A Th1 response was correlated with wart regression (63), and less severe HPV-associated disease $(64,65)$. Low levels of intratumoral IFN- $\gamma$ were related to a poor prognosis for SCCC (66). It was also demonstrated that in patients with HPV-associated lesions that are responsive to treatment with IFN- $\gamma$ the levels of Th1 cytokines and cellular recruitment were higher in responders than in nonresponders (67).

Several factors regulate the balance between Th1 and Th2 responses, such as cytokines produced by immunocompetent cells, antigen dose, costimulatory molecules and recruited APC (68). Although experimental evidence indicates that MHC molecules could participate in the regulation of Th1 and Th2 balance (69), the role of these molecules in this regulation remains unclear.

\section{p53 polymorphism and susceptibility to SCCC}

A p53 polymorphism in codon 72 has been described, which encodes either arginine or proline residues. Interestingly, the frequency of the arginine allele increases proportionally to the latitude, while the proline allele shows an inverse effect, i.e., it is more frequent in Black populations, and the arginine allele predominates among Caucasians (70).

Associations with this polymorphism in human cancers has been reported. Buller et al. (71) reported significant differences in the distribution of these p53 alleles between ovarian cancer patients and controls. Storey et al. (72) observed that the p53 arginine variant is more susceptible to HPV E6-mediated degradation than the proline variant. Furthermore, these authors have shown that individuals homozygous for the arginine allele had a 7 times higher chance to bear an HPV-associated SCCC than heterozygous proline/arginine women.

However, similar analyses performed in other populations did not confirm the association between such polymorphism of the p53 gene and the risk to develop HPV-associated lesions $(73,74)$. Our group is currently investigating this $\mathrm{p} 53$ polymorphism in a sample of Brazilian patients with HPV-positive SCCC and in healthy women. 
In conclusion, several reports indicate that genetic background is important to define higher or lower susceptibility to HPV infection and to SCCC, particularly polymorphisms of the MHC and p53 genes. The mechanisms by which these polymorphisms may influence the course of HPV infections and cervical lesions are under investigation. Such knowledge may contribute to defining better preventive and therapeutic approaches to control the burden of cervical cancer.

\section{References}

1. Pisani P, Parkin DM \& Ferlay J (1993). Estimates of the worldwide mortality from eighteen major cancers in 1985. Implications for prevention and projections of future burden. International J ournal of Cancer, 55: 891-903.

2. Villa LL (1997). Human papillomaviruses and cervical cancer. Advances in Cancer Research, 71: 321-341.

3. Muñoz N \& Bosch FX (1996). The causal link between HPV and cervical cancer and its implications for prevention of cervical cancer. Bulletin of the Pan American Health Organization, 30: 362-377.

4. Franco EL, Villa LL, Ruiz $A \&$ Costa MC (1995). Transmission of cervical human papillomavirus infection by sexual activity: differences between low and high oncogenic risk types. J ournal of Infectious Diseases, 172: 756-763.

5. zur Hausen H (1996). Papillomavirus infections - a major cause of human cancers. Biochimica et Biophysica Acta, 1288: F55-F78.

6. Lowy DR, Kirnbauer $R \&$ Schiller JT (1994). Genital human papillomaviruses. Proceedings of the National Academy of Sciences, USA, 91: 2436-2440.

7. Münger $K$, Phelps WC, Bubb V, Howley PM \& Schlegel R (1989). The E6 and E7 genes of the human papillomavirus type 16 together are necessary and sufficient for transformation of primary human keratinocytes. J ournal of Virology, 63: 44174421.

8. Villa LL \& Schlegel R (1991). Differences in transformation activity between HPV18 and HPV-16 map to the viral LCR-E6E7 region. Virology, 181: 374-377.

9. Lehn $H$, Villa LL, Marziona F, Hilgarth $M$, Hillemans HG \& Sauer G (1988). Physical state and biological activity of human papillomavirus genomes in precancerous lesions of the female genital tract. J ournal of General Virology, 69: 187-196.

10. J eon S \& Lambert PF (1995). Integration of human papillomavirus type 16 DNA into human genome leads to increased stability of E6 and E7 mRNAs: implications for cervical carcinogenesis. Proceedings of the National Academy of Sciences, USA, 92: 1654-1658.

11. Werness BA, Levine AJ \& Howley PM (1990). Association of human papillomavirus types 16 and $18 \mathrm{E} 6$ proteins with p53. Science, 248: 76-79.

12. Scheffner $M$, Werness $B A$, Huibregtse J M, Levine AJ \& Howley P (1990). The E6 oncoprotein encoded by human papillomavirus types 16 and 18 promotes the degradation of p53. Cell, 63: 1129-1136.

13. Dyson N, Howley PM, Münger K \& Harlow E (1989). The human papilloma virus-16 E7 oncoprotein is able to bind to the retinoblastoma gene product. Science, 243: 934-937.

14. Sellers WR \& Kaelin J r WG (1997). Role of the retinoblastoma protein in the pathogenesis of human cancer. J ournal of Clinical Oncology, 15: 3301-3312.

15. Evander $M$, Edlund $K$, Gustafsson $A$, J onsson $M$, Karlsson R, Rylander $E$ \& Wadell G (1995). Human papillomavirus infection is transient in young women: a population-based cohort study. J ournal of Infectious Diseases, 171: 1026-1030.

16. Londesborough P, Ho L, Terry G, Cuzick J, Wheeler C \& Singer A (1996). Human papillomavirus genotype as a predictor of persistence and development of highgrade lesions in women with minor cervical abnormalities. International J ournal of Cancer (Predictive Oncology), 69: 364368.

17. Remmink AJ, Walboomers JMM, Helmerhorst TJ M, Voorhorst FJ, Rozendaal L, Risse EKJ , Meijer CJ LM \& Kenemans P (1995). The presence of persistent high-risk HPV genotypes in dysplastic cervical lesions is associated with progressive disease: natural history up to 36 months. International J ournal of Cancer, 61: 306-311.

18. Ho GY, Burk RD, Kadish AS, Chang CJ , Palan P, Basu J, Tachezy R, Lewis R \& Romney S (1995). Persistent genital human papillomavirus infection as a risk factor for persistent cervical dysplasia. J ournal of the National Cancer Institute, 87: 1365-1371.
19. Villa LL, Rahal P \& Franco EL (1997). Molecular variant analysis as a tool in natural history studies of human papillomavirus infection and cervical neoplasia. In: Franco EL \& Monsonego J (Editors), New Developments in Cervical Screening and Prevention. Blackwell Science, Oxford.

20. Krensky AM (1997). The HLA system, antigen processing and presentation. Kidney International, 58 (Suppl): S2-S7.

21. Benacerraf B (1981). Role of MHC products in immune regulation. Science, 212: 1229-1238.

22. Han R, Breitburd F, Marche PN \& Orth $G$ (1992). Linkage of regression and malignant conversion of rabbit viral papillomas to MHC class II genes. Nature, 356: 6668.

23. Shepherd PS, Tran TTT, Rowe AJ, Cridland J C, Comeford SA, Chapman MG \& Rayfield LS (1992). T cell responses to the human papillomavirus type $16 \mathrm{E} 7$ protein in mice of different haplotypes. J ournal of General Virology, 73: 1269-1274.

24. Wank R \& Thomssen C (1991). High risk of squamous cell carcinoma of the cervix for women with HLA-DQw3. Nature, 352: 723-725.

25. Glew SS, Stern PL, Davidson J A \& Dyer PA (1992). HLA antigens and cervical carcinoma. Nature, 356: 22-23.

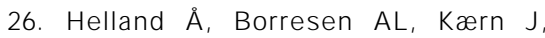
Ronningen KS \& Thorsby E (1992). HLA antigens and cervical carcinoma. Nature, 356: 22-23.

27. David ALM, Taylor GM, Gokhale D, Aplin JD, Seif MW \& Tindall VR (1992). HLA antigens and cervical carcinoma. Nature, 356: 22-23.

28. Vandenvelde $C$, De Foor $M \&$ Van Beers $D$ (1993). HLA-DQB1*03 and cenvical intraepithelial neoplasia grades I-III. Lancet, 341: 442

29. Wank R, Meulen J, Luande J, Eberhardt H \& Pawlita M (1993). Cenvical intraepithelial neoplasia, cervical carcinoma, and risk for patients with HLA-DQB $1 * 0602$, $* 0301, * 0303$ alleles. Lancet, 341: 1215.

30. Mehal WZ, Lo YMD, Herrington CS, Evans MF, Papadoulos MC, Odunsi K, Ganesan 
TS, McGee J O'D, Bell J \& \& Fleming KA (1994). Role of human papillomavirus in determining the HLA associated risk of cervical carcinogenesis. J ournal of Clinical Pathology, 47: 1077-1081.

31. Apple RJ , Erlich HA, Klitz W, Manos MM, Becker TM \& Wheeler CM (1994). HLA DR-DQ associations with cervical carcinoma show papillomavirus-type specificity. Nature Genetics, 6: 157-162.

32. Gregoire L, Lawrence WD, Kukuruga $D$, Eisenbrey AB \& Lancaster WD (1994). Association between HLA-DQB1 alleles and risk for cervical cancer in AfricanAmerican women. International J ournal of Cancer, 57: 504-507.

33. Nawa A, Nishiyama $Y$, Kobayashi $T$, Wakahara Y, Okamoto T, Kikkawa F, Suganuma N, Goto S, Kuzuya K \& Tomoda $Y$ (1995). Association of human leukocyte antigen-B1*03 with cervical cancer in $\mathrm{J}$ apanese women aged 35 years and younger. Cancer, 75: 518-521.

34. Apple RJ, Becker TM, Wheeler CM \& Erlich HA (1995). Comparison of human leukocyte antigen DR-DQ disease associations found with cervical dysplasia and invasive cervical carcinoma. J ournal of the National Cancer Institute, 87: 427-436.

35. Allen M, Kalantari M, Ylitalo N, Pettersson B, Hagmar B, Scheibenpflug L, J ohansson B, Petterson U \& Gyllensten U (1996). HLA DQ-DR haplotype and susceptibility to cenvical carcinoma: indications of increased risk for development of cervical carcinoma in individuals infected with HPV 18. Tissue Antigens, 48: 32-37.

36. Sastre-Garau $X$, Loste $M N$, VincentSalomon A, Favre M, Mouret E, Rochefordiere A De La, Durand J C, Tartour E, Lepage V \& Charron D (1996). Decreased frequency of HLA-DRB1*13 alleles in French women with HPV-positive carcinoma of the cervix. International J ournal of Cancer (Predictive Oncology), 69: 159-164.

37. Odunsi K, Terry G, Ho L, Bell J , CuzickJ \& Ganesan TS (1996). Susceptibility to human papillomavirus-associated cervical intra-epithelial neoplasia is determined by specific HLA DR-DQ alleles. International J ournal of Cancer, 67: 595-602.

38. Sanjeevi CB, Hjelmström P, Hallmans G, Wiklund $F$, Lenner $P$, Angström $T$, Dillner J \& LernmarkA (1996). Different HLA-DRDQ haplotypes are associated with cervical intraepithelial neoplasia among human papillomavirus type-16 seropositive and seronegative Swedish women. International J ournal of Cancer, 68: 409-414.

39. Helland $\AA$, Olsen AO, Gjøen K, Akselsen
HE, Sauer T, Magnus P, Børresen-Dale AL \& Rønningen KS (1998). An increased risk of cenvical intra-epithelial neoplasia grade II-III among human papillomavirus positive patients with the HLA-DQA1 *0102-DQB1*0602 haplotype: a population-based case-control study of Norwegian women. International J ournal of Cancer, 76: 19-24.

40. Bontkes HJ, Van Duin M, De Gruijl TD, Duggan-Keen MF, Walboomers J MM, Stukart MJ , Verheijen RHM, Helmerhorst TJ M, Meijer CJ LM, Scheper RJ , Stevens A, Dyer PA, Sinnott P \& Stern PL (1998). HPV 16 infection and progression of cervical intra-epithelial neoplasia: analysis of HLA polymorphism and HPV 16 E6 sequence variants. International J ournal of Cancer, 78: 166-171.

41. Montoya L, Saiz I, Rey G, Vela F \& ClericiLarradet N (1998). Cervical carcinoma: human papillomavirus infection and HLA-associated risk factors in the Spanish population. European J ournal of Immunogenetics, 25: 329-337.

42. Hildesheim A, Schiffman $M$, Scott DR, Marti D, Kissner T, Sherman ME, Glass AG, Manos MM, Lorincz AT, Kurman RJ , Buckland J, Rush B \& Carrington M (1998). Human leukocyte antigen class I/II alleles and development of human papillomavirus-related cervical neoplasia: results from a case-control study conducted in the United States. Cancer Epidemiology, Biomarkers and Prevention, 7: 10351041.

43. Ellis J RM, Keating PJ, Baird J, Hounsell $E F$, Renouf DV, Rowe $M$, Hopkins $D$, Duggan-Keen MF, Bartholomew J S, Young LS \& Stern PL (1995). The association of an HPV16 oncogene variant with HLA-B7 has implications for vaccine design in cervical cancer. Nature Medicine, 1: 464-470

44. Klenerman $P$ \& Zinkernagel RM (1998). Original antigenic sin impairs cytotoxic $T$ lymphocyte responses to viruses bearing variant epitopes. Nature, 394: 482-485.

45. Terry G, Ho L \& Cuzick J (1997). Analysis of E2 amino acid variants of human papillomavirus types 16 and 18 and their associations with lesion grade and HLA DR/ DQ type. International J ournal of Cancer, 73: 651-655.

46. McGuire W, Hill AVS, Allsopp CEM, Greenwood BM \& Kwjatkowski D (1994). Variation in the TNF- $\alpha$ promoter region associated with susceptibility to cerebral malaria. Nature, 371: 508-511.

47. Fijneman RJ A, Oomen LCJ M, Snoek M \& Demant $P$ (1995). A susceptibility gene for alveolar lung tumors in the mouse maps between Hsp70.3 and G7 within the H2 complex. Immunogenetics, 41: 106-109.

48. Lu S, Day NE, Degos L, Lepages V, Wang PC, Chan SH, Simons M, McKnight B, Easton D, Zeng Y \& de-Thé G (1990). Linkage of a nasopharyngeal carcinoma susceptibility locus to the HLA region. $\mathrm{Na}$ ture, 346: 470-471.

49. Klitz $\mathrm{W}$, Aldrich $\mathrm{CL}$, Fildes $\mathrm{N}$, Horning SJ $\&$ Begovich AB (1994). Localization of predisposition to Hodgkin disease in the HLA class II region. American J ournal of Human Genetics, 54: 497-505.

50. Manns A, Hanchard B, Morgan OSC Wilks R, Cranston B, Nam J, Blank M, Kuwayama M, Yashiki S, Fujiyoshi T, Blattner W \& Sonoda S (1998). Human leukocyte antigen class II associated alleles with human T-cell lymphotropic virus type I infection and adult T-cell leukemia/ lymphoma in a Black population. J ournal of the National Cancer Institute, 90: 617622.

51. Lee J E, Reveille J D, Ross MI \& Platsoucas CD (1994). HLA-DQB1*0301 association with increased cutaneous melanoma risk. International J ournal of Cancer, 59: 510513.

52. Iwatsuki $K$, Tagami $M$, Takigawa $M$ \& Yamada M (1986). Plane warts under spontaneous regression. Archives of Dermatology, 122: 655-659.

53. Nimako M, Fiander AN, Wilkinson GWG, Borysiewicz LK \& Man S (1997). Human papillomavirus-specific cytotoxic $T$ lymphocytes in patients with cervical intraepithelial neoplasia grade III. Cancer Research, 57: 4855-4861.

54. Evans EM, Man S, Evans AS \& Borysiewicz LK (1997). Infiltration of cervical cancer tissue with human papillomavirus-specific cytotoxic T-lymphocytes. Cancer Research, 57: 2943-2950.

55. Chen L, Thomas EK, Hu SL, Hellström I \& Hellström KE (1991). Human papillomavirus type 16 nucleoprotein E7 is a tumor rejection antigen. Proceedings of the $\mathrm{Na}$ tional Academy of Sciences, USA, 88: 110-114.

56. Vernon SD, Reeves WC, Clancy KA, Laga M, St Louis M, Gary HE, Ryder J r RW, Manoka AT \& Icenogle J P (1994). A longitudinal study of human papillomavirus DNA detection in human immunodeficiency virus type 1-seropositive and -seronegative women. J ournal of Infectious Diseases, 169: 1108-1112.

57. De Gruijl TD, Bontkes HJ, Walboomers J M, Stukart MJ, Doekhie FS, Remmink 
AJ, Helmerhorst TJ, Verheijen RH, Duggan-Keen MF, Stern PL, Meijer CJ \& Scheper RJ (1998). Differential T helper cell responses to human papillomavirus type 16 E7 relates to viral clearance or persistence in patients with cervical neoplasia: a longitudinal study. Cancer Research, 58: 1700-1706.

58. Kadish AS, Ho GY, Burk RD, Wang Y, Romney SL, Ledwidge R \& Angeletti RH (1997). Lymphoproliferative responses to human papillomavirus (HPV) type 16 proteins E6 and E7: outcome of HPV infection and associated neoplasia. J ournal of the National Cancer Institute, 89: 12851293.

59. Shepherd PS, Rowe AJ, Cridland J C, Coletart T, Wilson P \& Luxton J C (1996). Proliferative $T$ cell responses to human papillomavirus type $16 \mathrm{~L} 1$ peptides in patients with cervical dysplasia. J ournal of General Virology, 77: 593-602.

60. KonyaJ , Eklund C, af Geijersstam V, Yuan F, Stuber G \& Dillner J (1997). Identification of a cytotoxic T-lymphocyte epitope in the human papillomavirus type 16 E2 protein. J ournal of General Virology, 78: 2615-2620.

61. Höpfl R, Christensen ND, Angell MG \& Kreider J W (1995). Leukocyte proliferation in vitro against cottontail rabbit papillomavirus in rabbits with persisting papillomas/cancer or after regression. Archives of Dermatological Research, 287: 652658.

62. Mosmann TR, Cherwinski H, Bond MW, Giedlin MA \& Coffman RL (1986). Two types of murine helper T cell clone. Definition according to profiles of lymphokine activities and secreted proteins. J ournal of Immunology, 136: 2348-2357.
63. Grassegger A, Rollinger-Holzinger I, Zelger BWH, Heim K, Zwierzina H, Fritsch PO \& Höpfl RM (1997). Spontaneous or interferon- $\gamma$-induced T-cell infiltration, HLA-DR and ICAM-1 expression in genitoanal warts are associated with Th1 or mixed Th1/Th2 cytokine mRNA expression profiles. Archives of Dermatological Research, 289: 243-250.

64. Tsukui T, Hildesheim A, Schiffman $M H$, Luci III J , Contois D, Lawler P, Rush BB, Lorincz AT, Corrigan A, Burk RD, Qu W, Marshall MA, Mann D, Carrington $M$, Clerici M, Shearer GM , Carbone DP, Scott DR, Houghten RA \& Berzofsky J A (1996). Interleukin 2 production in vitro by peripheral lymphocytes in response to human papillomavirus-derived peptides: correlation with cervical pathology. Cancer Research, 56: 3967-3974.

65. Clerici M, Merola M, Ferrario E, Trabattoni $D$, Villa $M L$, Stefanon $B$, Venzon DJ, Shearer GM, De Paolo G \& Clerici E (1997). Cytokine production patterns in cervical intraepithelial neoplasia: association with human papillomavirus infection. J ournal of the National Cancer Institute, 89: 245-250.

66. Tartour E, Gey A, Sastre-Garau X, Surin IL, Mosseri V \& Fridman WH (1998). Prognostic value of intratumoral interferon gamma messenger RNA expression in invasive cervical carcinomas. J ournal of the National Cancer Institute, 90: 287-294.

67. Arany I \& Tyring SK (1996). Status of local cellular immunity in interferon-responsive and -nonresponsive human papillomavirus-associated lesions. Sexually Transmitted Diseases, 23: 475-480.

68. Abbas A, Murphy KM \& Sher A (1996). Functional diversity of helper T lympho- cytes. Nature, 383: 787-793.

69. Hanson MS, Cetkovic-Cvrlje M, Ramiya VK, Atkinson MA, Maclaren NK, Singh B, Elliott J F, Serreze DV \& Leiter EH (1996). Quantitative thresholds of MHC Class II I$\mathrm{E}$ expressed on hemopoietically derived antigen-presenting cells in transgenic NOD/Lt mice determine level of diabetes resistance and indicate mechanism of protection. J ournal of Immunology, 157: 1279-1287.

70. Beckman G, Birgander R, Själander A Saha N, Holmberg $P \AA \AA$, Kivelä $A \&$ Beckman L (1994). Is p53 polymorphism maintained by natural selection? Human Heredity, 44: 266-270.

71. Buller RE, Sood A, Fullenkamp C, Sorosky J, Powills K \& Anderson B (1997). The influence of the p53 codon 72 polymorphism on ovarian carcinogenesis and prognosis. Cancer Gene Therapy, 4: 239245.

72. Storey A, Thomas M, Kalita A, Harwood C, Gardiol D, Mantovani F, Breuer J , Leigh IM, Matlashewski G\& Banks L (1998). Role of a p53 polymorphism in the development of human papillomavirus-associated cancer. Nature, 393: 229-234.

73. Rosenthal AN, Ryan A, Al-J ehani RM, Storey A, Harwood CA \& J acobs IJ (1998). p53 codon 72 polymorphism and risk of cervical cancer in UK. Lancet, 352: 871872

74. Minaguchi $T$, Kanamori $Y$, Matsushima $M$, Yoshikawa H, Taketani $Y \& \&$ Nakamura $Y$ (1998). No evidence of correlation between polymorphism at codon 72 of p53 and risk of cervical cancer in J apanese patients with human papillomavirus $16 / 18$ infection. Cancer Research, 58: 45854586. 